Article

\title{
Remediation of Cd (II) Ion from an Aqueous Solution by a Starch-Based Activated Carbon: Experimental and Density Functional Theory (DFT) Approach
}

\author{
Saad Melhi ${ }^{1}$, , Saeed Ullah Jan ${ }^{2, *}$, Adnan Ali Khan ${ }^{2}$, Khan Badshah ${ }^{2}$, Saeed Ullah ${ }^{2}$, Bushra Bostan ${ }^{2}$ \\ and Zeliha Selamoglu ${ }^{3}$ (D)
}

check for

updates

Citation: Melhi, S.; Ullah Jan, S.;

Khan, A.A.; Badshah, K.; Ullah, S.;

Bostan, B.; Selamoglu, Z.

Remediation of Cd (II) Ion from an

Aqueous Solution by a Starch-Based

Activated Carbon: Experimental and

Density Functional Theory (DFT)

Approach. Crystals 2022, 12, 189.

https://doi.org/10.3390/

cryst12020189

Academic Editor: Sergio Brutti

Received: 15 December 2021

Accepted: 24 January 2022

Published: 27 January 2022

Publisher's Note: MDPI stays neutral with regard to jurisdictional claims in published maps and institutional affiliations.

Copyright: (C) 2022 by the authors. Licensee MDPI, Basel, Switzerland. This article is an open access article distributed under the terms and conditions of the Creative Commons Attribution (CC BY) license (https:// creativecommons.org/licenses/by/ $4.0 /)$.
1 Department of Chemistry, College of Science, University of Bisha, Bisha 61922, Saudi Arabia; saadmelhi@ub.edu.sa

2 Department of Chemistry, University of Malakand, Chakdara 18800, Pakistan; Adnan.chem@uom.edu.pk (A.A.K.); Khan.badshah@uom.edu.pk (K.B.); saeedchemist01@gmail.com (S.U.); bushrabostan1@gmail.com (B.B.)

3 Department of Medical Biology, Faculty of Medicine, Nigde Omer Halisdemir University, 51240 Nigde, Turkey; zselamoglu@ohu.edu.tr

* Correspondence: Sujan1973@uom.edu.pk

\begin{abstract}
Heavy metal ion pollution is a serious threat for aquatic and terrestrial living beings. Adsorption is a facile process to encounter heavy metal pollution. Various types of adsorbents have been developed and used for environmental remediation. Activated carbon is one of the cheapest adsorbents derived from various biomass. In this work, the adsorption of cadmium ions (Cd (II)) with starch-based activated carbon (AC) having a specific surface area of $1600 \mathrm{~m}^{2} \mathrm{~g}^{-1}$ was investigated in a series of batch laboratory studies. The effective operating parameters, such as initial $\mathrm{pH}\left(\mathrm{pH}_{0}\right)$, initial concentration of metal ions, contact time, and temperature on the adsorption, were investigated. Validation of the kinetic study shows that the adsorption process is better predicted by the pseudo-second-order model. The extended Freundlich and Langmuir isotherms were applied to the study. The results show that the metal ion adsorption capacities of activated carbon increased with increasing $\mathrm{pH}$, and it was found that maximum adsorption $\left(284 \mathrm{mg} \mathrm{g}^{-1}\right)$ of $\mathrm{Cd}$ (II) was achieved at $\mathrm{pH}$ solution of 5.5-6. The thermodynamic parameters, such as $\Delta G, \Delta H$, and $\Delta S$, were found to be $-17.42 \mathrm{~kJ} \mathrm{~mol}^{-1}, 8.49 \mathrm{~kJ} \mathrm{~mol}^{-1}$, and $58.66 \mathrm{~J} \mathrm{~mol}^{-1} \mathrm{~K}^{-1}$, respectively, revealing that the adsorption mechanism is endothermic, spontaneous, and feasible. Furthermore, the density functional theory simulations demonstrated that the activated carbon strongly interacted with toxicity and mobility, so it is very urgent to remove this species from industrial wastewater before it is discharged into the environment. The adsorption energy calculated for all interactive sites was negative $\left(-43.41 \mathrm{~kJ} \mathrm{~mol}^{-1}\right.$ to $-967.74 \mathrm{~kJ} \mathrm{~mol}^{-1}$ ), showing effective interaction between the adsorbate and adsorbent. The PDOS clearly shows that there is a stronger overlapping at the Femi level between the $\mathrm{d}$ orbital of the $\mathrm{Cd}$ ion and the $\mathrm{p}$ orbital of the $\mathrm{O}$ atom, showing a strong interaction and confirming the chemical bond formation between the $\mathrm{Cd}$ (II) ion and $\mathrm{O}$ atom.
\end{abstract}

Keywords: adsorption; DFT; cadmium (II) ion; activated carbon; kinetics; thermodynamics

\section{Introduction}

Due to rapid industrialization and urbanization, heavy metal concentrations have increased enormously in water reservoirs. The rate of depletion of water reservoirs is alarming and is a serious environmental problem [1-3]. Clean water vitality cannot be compromised in any case. The large number of pollutants have been identified from industrial and domestic sources and include antibiotics, dyes, phenols, insecticides, and heavy metals constituents $[4,5]$. Due to their non-degradable and accumulative nature, heavy metals are extremely harmful to living organisms. Among heavy metals, nontritive 
cadmium (II) metal is classified as a human teratogen, carcinogen, and the most dangerous priority water pollutant with a biological half-life of $10-30$ years [6,7].

The main sources of $\mathrm{Cd}$ (II) ion contamination are industrial wastewater, combustion of oil, and coal waste incineration. Cd (II) is extensively used in different industrial processes, e.g., as a coloring pigment, anticorrosive agent, fabrication of batteries, and in nuclear power plants as an absorber of neutrons. It has been estimated that about 7000 tons/annum has been released on a global level [8]. According to the World Health Organization (WHO), the permissible level of Cd (II) is less than $0.003 \mathrm{mg} \mathrm{dm}^{-3}$ for drinking water [8]. Cd (II) has noxious effects on the lungs, liver, and kidneys, even in a very low concentration [9-11]. The inhalation of Cd (II) contaminated air can cause shortness of breath, damage of mucous membranes, and lung edema. The intake of food contaminated with Cd (II) can cause diarrhea and severe vomiting. Similarly, it can cause bone damage, infertility, prostate cancer, and tumors $[12,13]$. So, it is pertinent for human health and environmental safety to ascertain the concentration of Cd (II) on a regular basis and to develop techniques for the capturing of Cd (II) ion before it is discharged into bodies of water.

Several techniques, such as reverse osmosis, ion exchange, chemical precipitation, electrolytic extraction, redox method, and electrodialysis, have been designed and applied for the scavenging of heavy metals. However, these methods have their limitations, e.g., long processing times, high energy consumption, and poor sequestration of heavy metals [14].

The adsorption technique is as efficient as it is simple in operation, cost-effective, and environmentally friendly [1]. A variety of adsorbents, such as silica gel [15,16], clay [17,18], and bio-sorbents [19], have already been reported for the sequestration of heavy metals from wastewater. Theoretical analysis is a complementary tool to know the mechanism of the absorption process [20-22]. The efficiency of ACs as adsorbents for diverse types of pollutants is well reported [23]. It is well known that activated carbon has been found to be much more efficient for removing organic compounds than metals and other inorganic pollutants. Efforts are ongoing to substantially improve the potential of carbon surfaces by using different chemicals or suitable treatment methods, which will enable AC to enhance its potential for the removal of specific contaminants from the aqueous phase. The physical and chemical structure of carbon could be changed by various methods, i.e., activation conditions (different agents, temperature, and time of the process), precursor, and additives, etc.

Starch-based activated carbon was prepared and characterized to remove Cd (II) ions from spiked water. For the determination of the adsorption mechanism, the data were subjected to different adsorption models. The sorption obeys second-order kinetics, Freundlich and Langmuir isotherms, and was more favorable at $\mathrm{pH}$ 6. For the determination of thermodynamic parameters of the adsorption mechanism, the temperature study was carried out, which shows that the adsorption was spontaneous, feasible, and of endothermic nature. The DFT supported the experimental findings.

\section{Experimental Section}

\subsection{Materials}

The chemicals such as $\mathrm{CdCl}_{2}$, dithizone, $\mathrm{NaOH}, \mathrm{HCl}, \mathrm{KOH}, \mathrm{CH}_{3} \mathrm{COOH}, \mathrm{CH}_{3} \mathrm{COONa}$, $\mathrm{H}_{3} \mathrm{BO}_{3}$, and $\mathrm{NaOH}$ of analytical grade were supplied by Sigma-Aldrich (Pvt.) Ltd. (Karachi, Pakistan) and were used without any further purification. The solutions of buffer 1-7 with the ionic strength of $10 \mathrm{mmol}$ were prepared by taking the calculated amount of $\mathrm{KCl}$ and $\mathrm{HCl}$ for buffer 1-2, $\mathrm{CH}_{3} \mathrm{COOH}$, and $\mathrm{CH}_{3} \mathrm{COONa}$ for buffer 3-6, and $\mathrm{NaOH}$ and $\mathrm{H}_{3} \mathrm{BO}_{3}$ for buffer 7. $\mathrm{CdCl}_{2}$ was mixed with dithizone in $2 \mathrm{M} \mathrm{NaOH}$ to obtain orange-colored Cd-dithizone complex (Figure 1), and its absorbance was studied at $549 \mathrm{~nm}$ wavelength as compared to the standard [24]. 

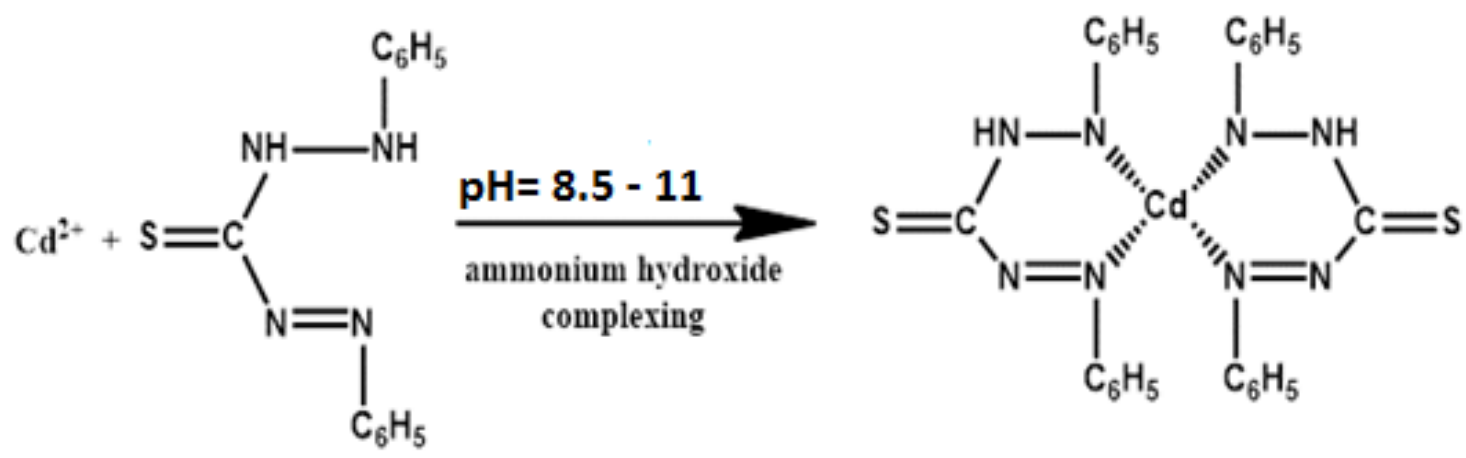

Figure 1. Cadmium dithizone complex.

The concentration of Cadmium (II) ions was determined from its complex with dithizone in the presence of non-ionic surfactant, e.g., CTAB. The molar absorptivity of the complex becomes almost double as compared to the standard method, and a very small amount of $\mathrm{Cd}^{+2}$ can be determined spectrometrically at a wavelength of $549 \mathrm{~nm}$. The increase in the molar absorptivity and rate constant are due to the micelle, which favors the formation of a Cd (II) ion and dithizone complex.

$$
\begin{gathered}
\text { Reaction: } \mathrm{Cd}^{2+}+\mathrm{n} \text { dithizone } \leftrightharpoons \text { Complex } \\
\mathrm{k}=\frac{[\text { Complex }]}{\left[\mathrm{Cd}^{+2}\right][\text { Dithizone }]^{\mathrm{n}}} \leftrightharpoons \frac{[\text { Complex }]}{[\mathrm{Cd}]^{+2}}=\mathrm{k}[\text { Dithizone }]^{\mathrm{n}}
\end{gathered}
$$

\subsection{Synthesis of Adsorbent}

The starch sample was sieved by 300 mesh size and mixed with potassium hydroxide in a 1:4 weight ratio and activated at $850{ }^{\circ} \mathrm{C}$ for $90 \mathrm{~min}$ with argon at $3{ }^{\circ} \mathrm{C} / \mathrm{min}$ rise. The product obtained was thoroughly washed again and again with $5 \mathrm{wt}$. \% $\mathrm{HCl}$ followed by washing with double-distilled water until the product was neutralized and dried at $120^{\circ} \mathrm{C}$ overnight. The product thus obtained was named starch-based activated carbon (AC) and characterized by BET, SEM, TEM, XRD, FT-IR, TGA, and zeta potential [25].

\subsection{Adsorption Experiment}

Glass culture tubes with a given amount of adsorbent and a specific volume of sorbate with a known concentration were used in the batch mode experiments at room temperature or specified otherwise. The culture tubes were shaken on a wrist-action shaker (Model Burrell 75, Burrell Scientific, Pittsburgh, PA, USA). After shaking, the concentration of $\mathrm{Cd}$ (II) was recorded by using a double-beam UV-Visible spectrophotometer (Labomed, Inc. UVD 2960, Los Angeles, CA, USA). The adsorbed amount of Cd(II) and the distribution coefficient $\left(K_{d}\right)$ were determined through the following equations:

$$
\begin{gathered}
\% \text { Adsorption }=\frac{\mathrm{Ci}-\mathrm{Ce}}{\mathrm{Ci}} \times 100 \\
K_{d}=\frac{\text { Amount of } \mathrm{Cd}(\mathrm{II}) \text { ion adsorbed onto sorbent }}{\text { Amount of } \mathrm{Cd}(\mathrm{II}) \text { ion remaining in the solution }} \times \frac{\mathrm{V}}{\mathrm{W}}
\end{gathered}
$$

where $C_{i}$ is the initial $C d$ (II) concentration, $C$ is the equilibrium concentration, $W$ is weight of the sorbent, and $V$ is the volume of Cd (II) ions solution.

All the experiments were carried out in triplicate at room temperature or described otherwise. The linear regression of the data was carried out and was in the range of 1-0.997 for all analyses. 


\section{Results and Discussion}

\subsection{Material Characterization}

The activated carbon derived from starch was used for the adsorption of Cd (II) ions from industrial wastewater. The material was characterized through the following techniques.

\subsubsection{SEM and TEM Analysis}

The SEM images of the AC derived from starch at different resolutions illustrate the sheet-type morphology that ranges from nanometers to several micrometers (Figure 2a,b), whereas the TEM images at low and high magnification further confirm the multilayer nature of the individual sheet for the obtained activated carbon (Figure 2c,d) [26].
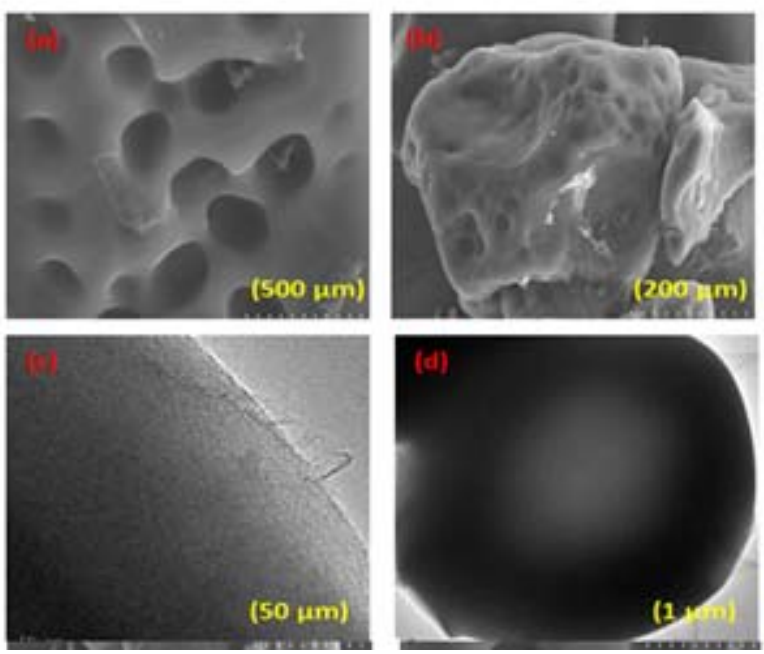

Figure 2. (a,b) SEM images of the starch-based AC and (c,d) TEM images of starch-based AC.

\subsubsection{AFM Analysis}

An AFM technique was performed further to investigate the average and maximum height of the AC. Figure 3a,b shows 3-dimensional (3D) patterns of starch-based AC with particle heights that varied from 5 to $40 \mathrm{~nm}$ [27]. Thus, through the AFM technique, we could guess the maximum height $(40 \mathrm{~nm})$ of the multilayer AC sheets, which makes it an attractive choice for toxic $\mathrm{Cd}$ (II) ion adsorption [23].

(a)

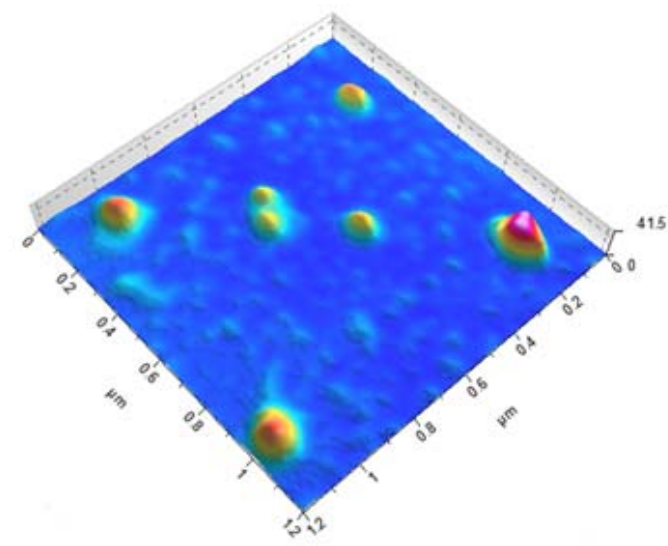

(b)

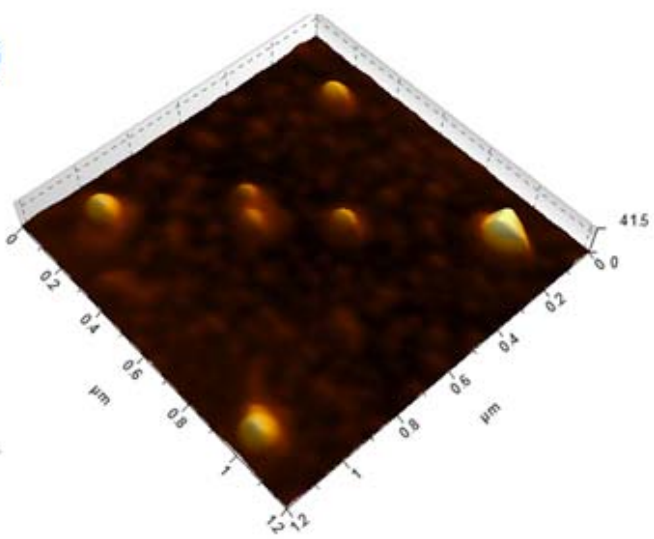

Figure 3. AFM (a,b) 3D images of the starch-based AC.

\subsubsection{FT-IR Analysis}

FT-IR analysis is used to confirm different groups on the surface of AC (Figure 4). The broader peak at $3450 \mathrm{~cm}^{-1}$ corresponds to the hydroxyl group [28]. The absorption peak at 2920 is due to $-\mathrm{CH}_{3}$, and the peak at $1630 \mathrm{~cm}^{-1}$ is due to $-\mathrm{C}=\mathrm{O}$ vibration [29]. The peaks 
on 1550 and $1120 \mathrm{~cm}^{-1}$ represent $-\mathrm{NO}_{2}$ and $-\mathrm{SO}_{3} \mathrm{H}$ groups, respectively [30]. The spectra indicate that the starch-based AC contains aromatic rings [31].

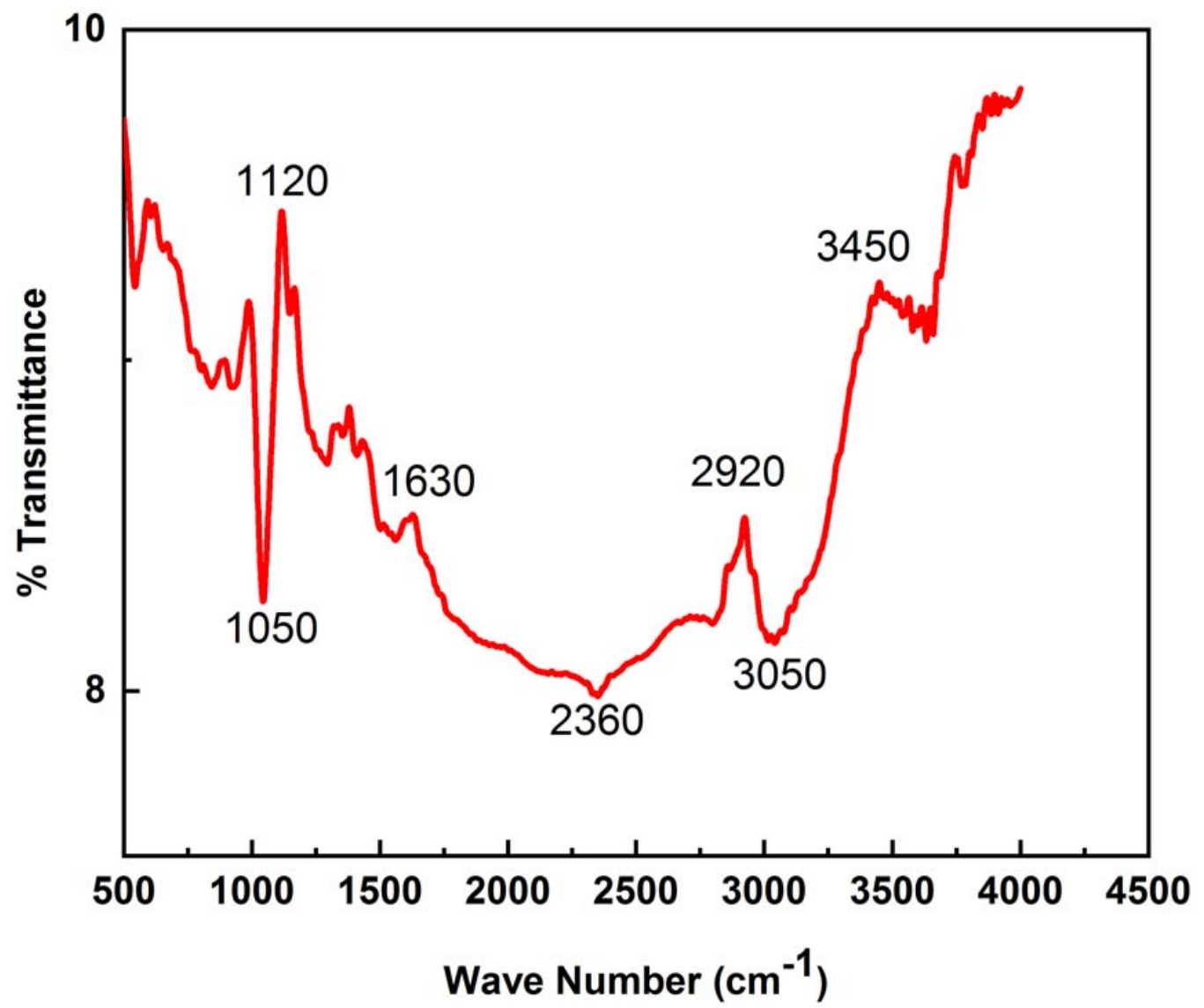

Figure 4. FTIR spectra of starch-based AC.

\subsubsection{TGA Study}

The thermal stability of the starch-based AC was studied at temperatures up to $1000{ }^{\circ} \mathrm{C}$ The total 14\% weight loss was observed from the total mass of the AC, and this may be due to the conversion of the starch-based $\mathrm{AC}$ into $\mathrm{CO}$ and $\mathrm{CO}_{2}$ [32] and some other compounds at various temperatures [33]. It remained stable, it can be concluded that the starch-based $\mathrm{AC}$ was stable at a very high temperature up to $1000{ }^{\circ} \mathrm{C}$ (Figure 5).

\subsubsection{Zeta Potential and Zeta Sizer Analysis}

Particle size distribution is a useful parameter to elucidate the arrangement of particle size in the adsorbents, while its zeta potential determines the surface charge required for dispersion. Figure 6 shows the size distribution and zeta potential plots of the AC, which reveals that the average particle size was $575 \mathrm{~nm}$ and polydispersity index (PDI) of 0.635 , representing sufficient variation in sizes. Its surface charge was $-16.9 \mathrm{mV}$, which is sufficient to remain suspended [34]. 


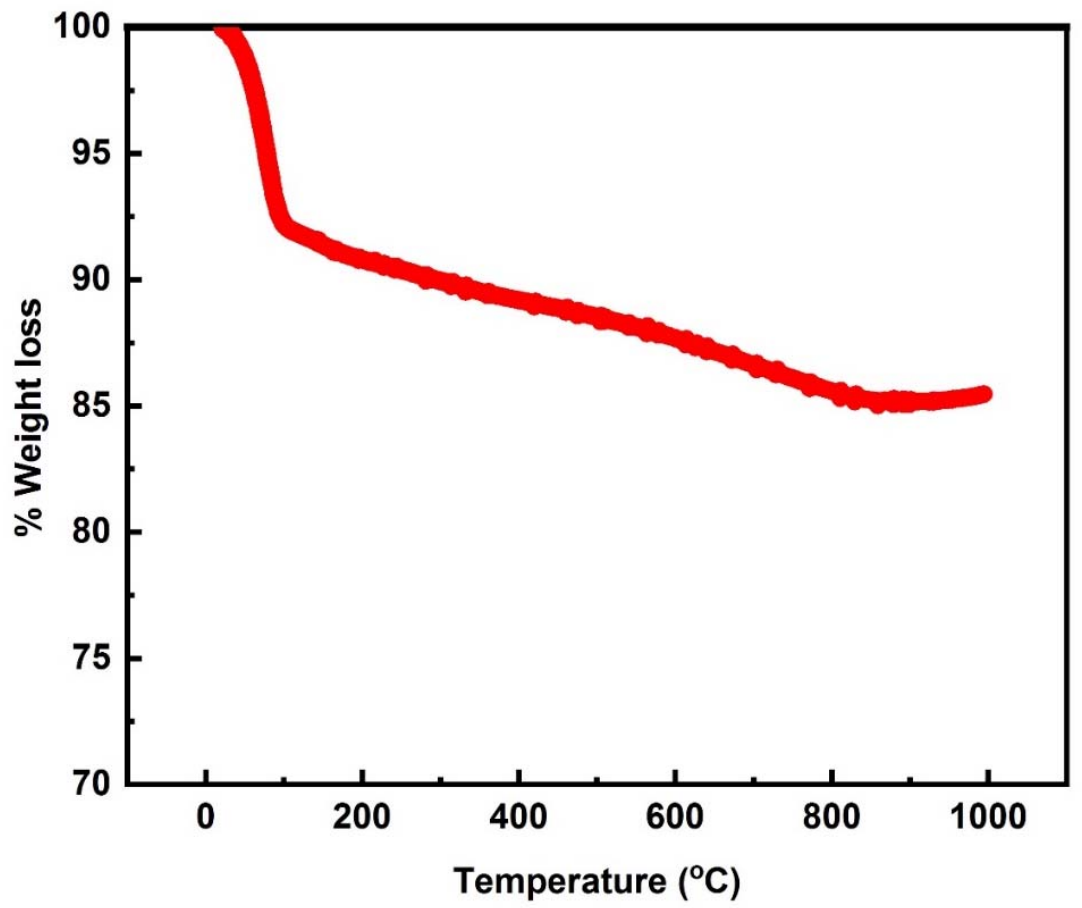

Figure 5. TGA plot of the starch-based AC.
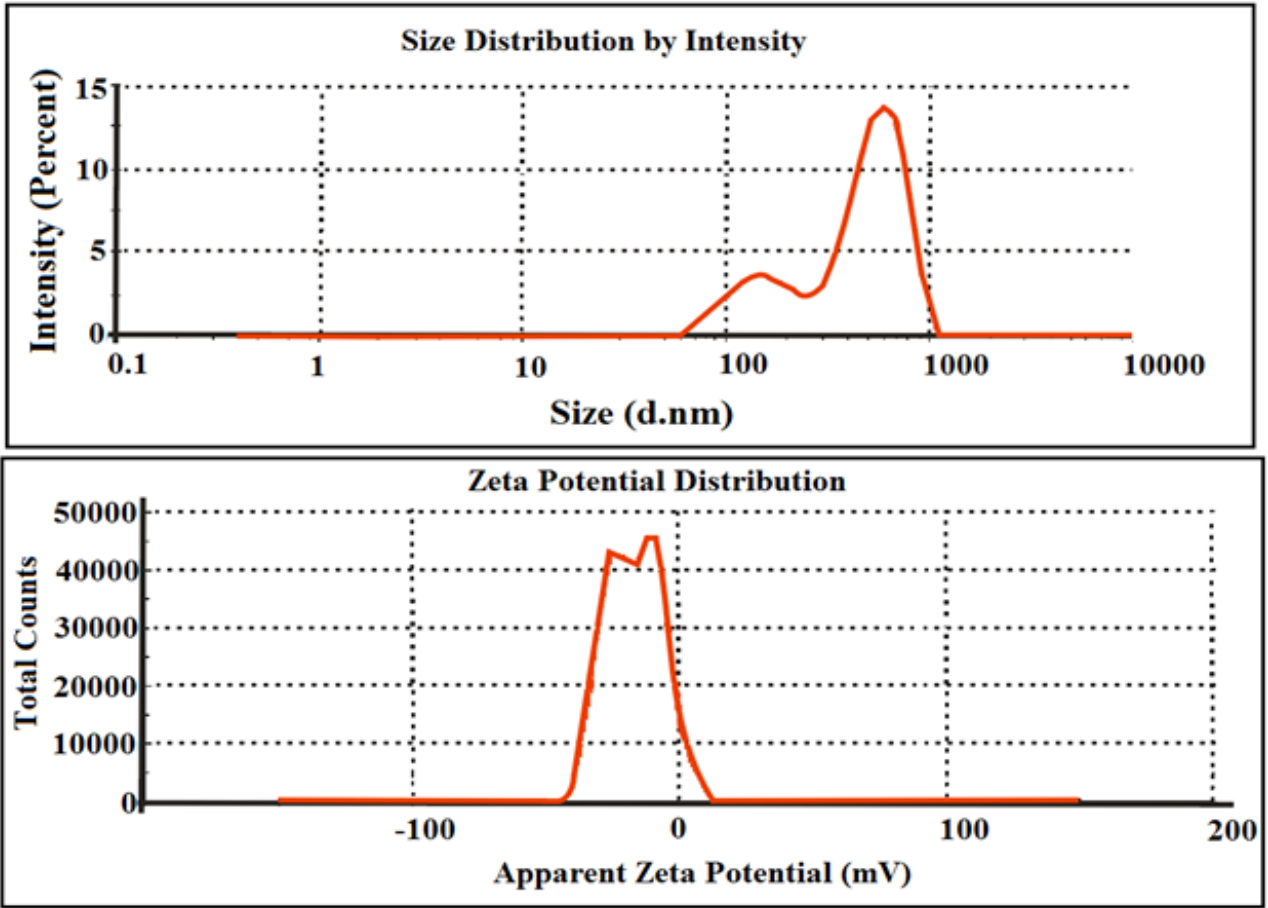

Figure 6. Zeta sizer and zeta potential of the starch-based AC.

\subsubsection{BET and BJH Analysis}

The surface area was found to be $1600 \mathrm{~m}^{2} \mathrm{~g}^{-1}$ of starch-derived $\mathrm{AC}$, as determined from a BET isotherm with a porous structure (Figure 7). The BJH analysis shows that $\mathrm{AC}$ has microspores and mesopores on its surface (inset of Figure 7a). The BET isotherm (Figure $7 \mathrm{~b}$ ) shows the surface area of $\mathrm{Cd}$ (II) ions loaded AC, which is only $13.35 \mathrm{~m}^{2} \mathrm{~g}^{-1}$ against the previous prestine AC surface area, which was $1600 \mathrm{~m}^{2} \mathrm{~g}^{-1}$, reflecting that most of the surface has been covered by the metal ions. 
(a)

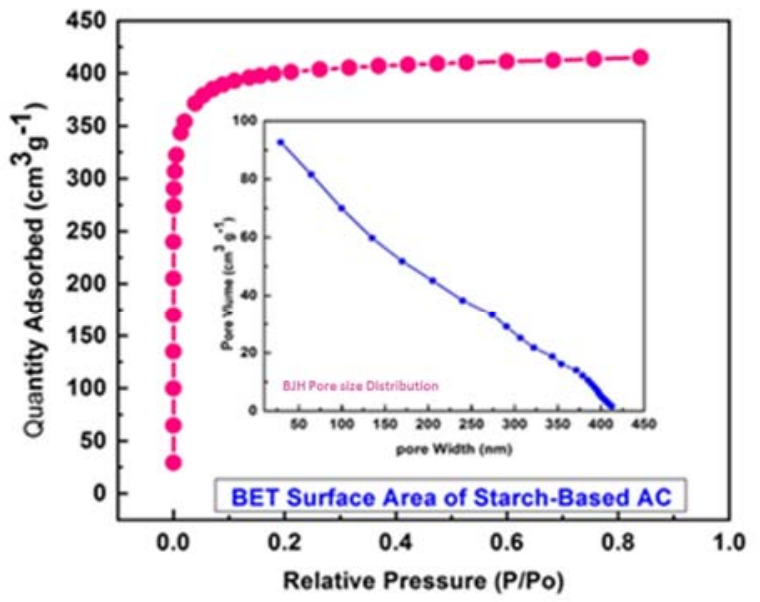

(b)

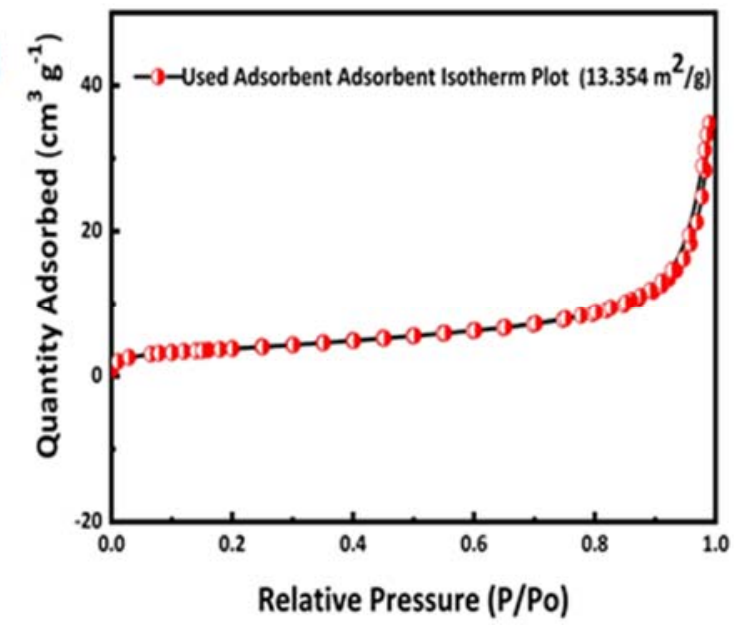

Figure 7. (a) Nitrogen sorption isotherm of starch-based AC at $77.5 \mathrm{~K}$ with inset of BJH pore size distribution and (b) BET isotherm of the Cd (II)-ion-loaded AC.

\subsection{Adsorption Experiments}

\subsubsection{Effect of $\mathrm{pH}$ on Sorption}

The sorption capacity is greatly influenced by the medium [2]. The effect of $\mathrm{pH}$ on the adsorption of $\mathrm{Cd}$ (II) was investigated at $\mathrm{pH}$ 1.0-9.0. The concentration of sorbate of $100 \mathrm{mg} \mathrm{L}^{-1}$, sorbent amount of $30 \mathrm{mg}$, and shaking time of $120 \mathrm{~min}$ were chosen arbitrarily. The equilibrium uptake of Cd (II) increased notably up to $\mathrm{pH} 6$ and then decreased continuously. The maximum uptake (98.58\%) was observed at $\mathrm{pH} 6$ and was selected for further experiments. At acidic $\mathrm{pH}$, the electrostatic repulsion is created between the protonated surface of $\mathrm{AC}$ and $\mathrm{Cd}$ (II) metal ions. These observations also have been reported by other researchers $[6,35]$. Beyond $\mathrm{pH} 6$, the adsorption capacity decreased due to the formation of $\mathrm{Cd}(\mathrm{OH})_{2}$ (cadmium hydroxide) [36]. The reaction mechanism involved is written as below.

$$
\begin{gathered}
\mathrm{Cd}^{+2}+\mathrm{H}_{2} \mathrm{O} \rightleftharpoons \mathrm{Cd}(\mathrm{OH})^{+}+H^{+} p k_{1}=9.0 \\
\mathrm{Cd}^{+2}+2 \mathrm{H}_{2} \mathrm{O} \rightleftharpoons \mathrm{Cd}(\mathrm{OH})_{2}{ }^{+}+2 H^{+} p k_{2}=19.09 \\
\mathrm{Cd}^{+2}+3 \mathrm{H}_{2} \mathrm{O} \rightleftharpoons \mathrm{Cd}(\mathrm{OH})_{3}{ }^{+}+3 H^{+} p k_{3}=30.2 \\
\mathrm{Cd}^{+2}+2 \mathrm{H}_{2} \mathrm{O} \rightleftharpoons \mathrm{Cd}(\mathrm{OH})_{\mathrm{S}}{ }^{+}+2 H^{+} p k s=30.2
\end{gathered}
$$

\subsubsection{Influence of the AC Dose}

The influence of the dose of the AC on the adsorption of $\mathrm{Cd}$ (II) ion was tested at AC dose ranges of 0.01-0.035 g Figure 8a. The rate of adsorption increased at the AC dose up to $0.025 \mathrm{~g}$, and then it remained constant. Thus, $0.025 \mathrm{~g}$ was used as the standard for further experiments.

\subsubsection{Influence of Shaking Time}

The influence of shaking time on Cd (II) ion removal was investigated between 0 and $50 \mathrm{~min}$. The equilibrium was attained within $40 \mathrm{~min}$ and was selected for further investigations (Figure 8b). The adsorption rate of Cd (II) ions was high initially as abundant vacant sites were available, and after that, the movement of the ions was intraparticle, which was a relatively slow process. 
(a)

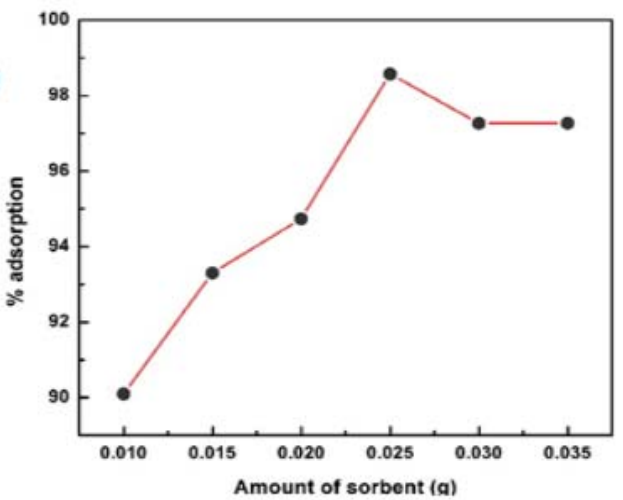

(c)

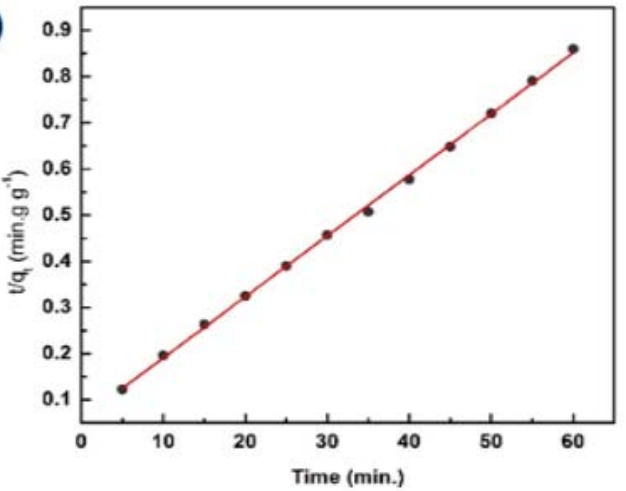

(b)

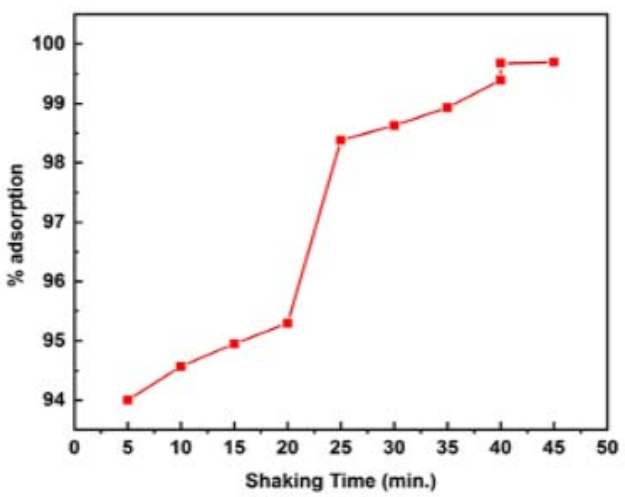

(d)

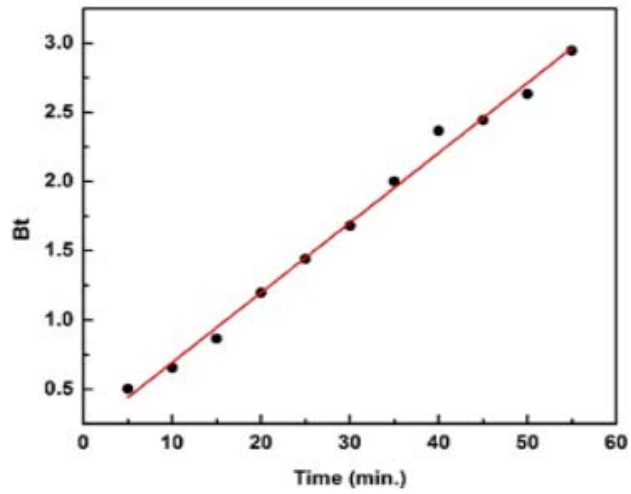

Figure 8. (a) Effect of amount of AC, (b) effect of shaking time, (c) pseudo-second-order kinetic model, and (d) Reichenberg model.

The mass transfer during the process in the rate-determining step can be determined by using kinetic models $[2,37,38]$. The pseudo-second-order equation applied in the following linear form was the best-fitted:

$$
\frac{t}{q_{t}}=\frac{1}{k_{2} q_{e}^{2}}+\frac{1}{q_{e}} t
$$

where $k_{2}$ rate constant and $q_{e}$ can be determined from the slope Figure $8 \mathrm{c}$, and their magnitudes are calculated and listed in Table 1. The experimental and theoretical values of $q_{e}$ are in close agreement with each other, indicating the applicability of the model.

Table 1. Kinetic parameters of Cd (II) ion adsorption onto starch-based AC.

\begin{tabular}{ccccc}
\hline Kinetic Models & $\begin{array}{c}\text { Rate Constant } \\
\left(\boldsymbol{k}_{\mathbf{1}} \text { and } \mathbf{k}_{\mathbf{2}}\right) \\
\left(\mathbf{g ~ m}^{-\mathbf{1}} \mathbf{~ m i n ~}^{-1}\right)\end{array}$ & $\boldsymbol{q}_{e, \text { cal }}\left(\mathbf{m g ~ g}^{-\mathbf{1}}\right)$ & $\begin{array}{c}\boldsymbol{q}_{e, \text { exp }} \\
\left(\mathbf{m g ~ g}^{-1}\right)\end{array}$ & $\mathbf{R}^{\mathbf{2}}$ \\
\hline $\begin{array}{c}\text { Pseudo-first-order } \\
\text { Pseudo-second-order }\end{array}$ & 0.033 & 1.00 & 0.27466 & 0.951 \\
\hline
\end{tabular}

The Reichenberg equation was used in the following form in order to further explore the mechanism [39]:

$$
\begin{gathered}
F=\left(\frac{1-6}{\pi^{2}}\right) e^{-B_{T}} \\
B_{T}=-0.4977 \ln (1-F)
\end{gathered}
$$

where $F$ is the ratio of $q_{t}$ and $q_{e}$ and $B_{T}$ is a constant (Figure $8 \mathrm{~d}$ ), showing that both film diffusion and intraparticle diffusion are involved in the mechanism. 


\subsubsection{Effect of Cd (II) Ion Solution Concentration}

The effect of Cd (II) ion solution concentration was studied at 10-160 $\mathrm{mg} \mathrm{L}^{-1}$ (Figure 9b). The maximum rate of removal of adsorbate was at $80 \mathrm{mg} \mathrm{L}^{-1}$, and then it remained constant $[40,41]$, thus, $80 \mathrm{mg} \mathrm{L}^{-1}$ was used as the standard for further experiments.

(a)

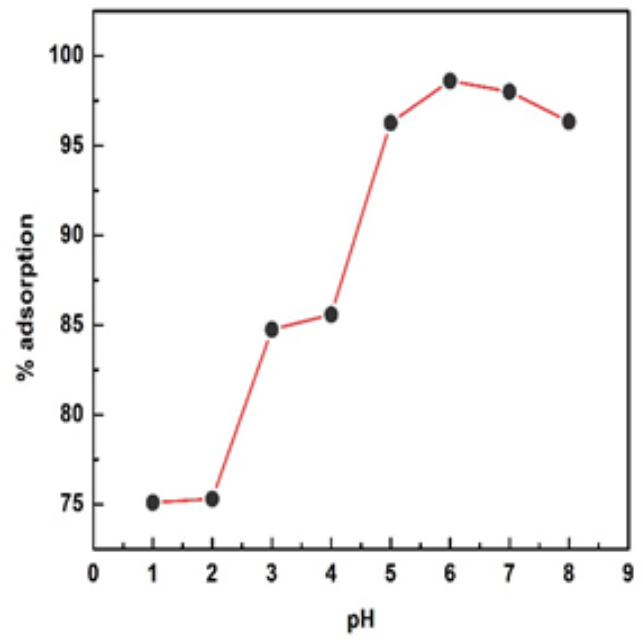

(c)

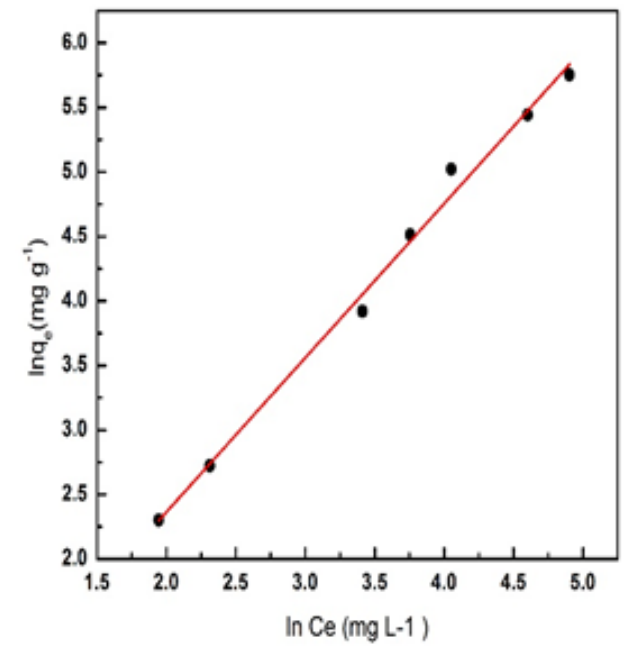

(b)

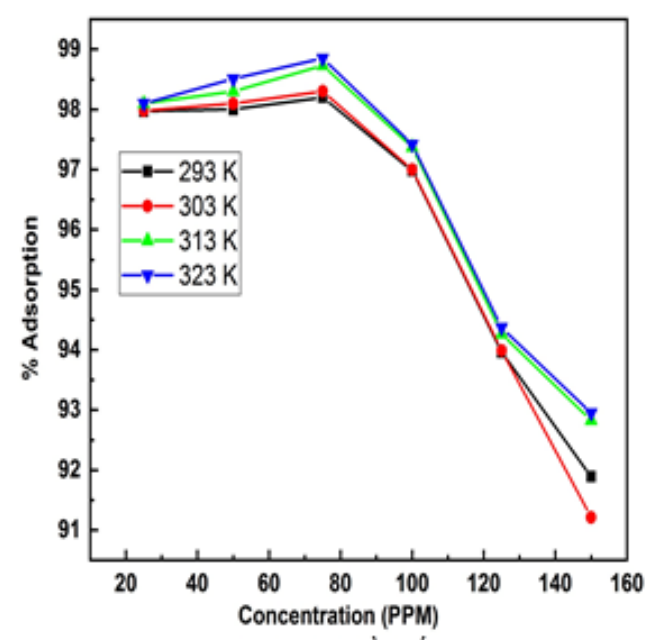

(d)

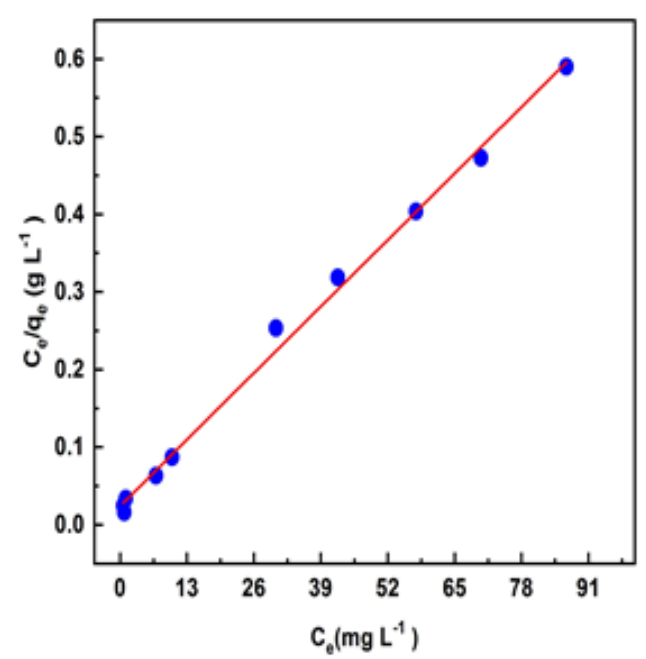

Figure 9. (a) Effect of pH, (b) effect of concentration, (c) Freundlich, and (d) Langmuir isotherms.

The Langmuir equation was used in the following form [42]:

$$
\frac{\mathrm{C}_{\mathrm{e}}}{q_{e}}=\frac{\mathrm{C}_{\mathrm{e}}}{Q_{\max }}+\frac{1}{K_{L} Q_{\max }}
$$

where $Q_{\max }$. is the amount adsorbed, $K_{L}, q_{e}$, and $\mathrm{C}_{\mathrm{e}}$ were calculated from the slope and intercept of the graph(Figure 9d), and their magnitudes are listed in Table 1. The adsorbate affinity $\left(R_{L}\right)$ is represented below:

The $R_{L}(0.0011)$ indicating favorable adsorption $[43,44]$.

$$
R_{L}=\frac{1}{1+K_{L} C_{e}}
$$

The Freundlich equation was used in the following form [45]:

$$
\log q_{e}=\log K_{F}+\frac{1}{n} \log C_{e}
$$


where the adsorption capacity $\left(K_{F} \mathrm{mmol}^{1-1 / n} \mathrm{~kg}^{-1} \mathrm{~L}^{1 / n}\right)$ and $1 / n$ represented the surface heterogeneity and can be calculated from the slope and intercept of the graph (Figure 9c). The Freundlich parameters are tabulated in Table $2[46,47]$.

Table 2. Langmuir and Freundlich parameters along with correlation coefficients for the adsorption of $\mathrm{Cd}$ (II) ion onto $\mathrm{AC}$ at $\mathrm{pH} 6$.

\begin{tabular}{|c|c|c|c|c|c|c|c|}
\hline \multirow[b]{2}{*}{ Temperature (K) } & \multicolumn{4}{|c|}{ Langmuir Parameters } & \multicolumn{3}{|c|}{ Freundlich Parameters } \\
\hline & $Q_{\max .}\left(\mathrm{mg} \mathrm{g}^{-1}\right)$ & $K_{L\left(\mathrm{mmol} \cdot \mathrm{L}^{-1}\right)}$ & $R_{L}$ & $\mathbf{R}^{2}$ & $\begin{array}{c}K_{F} \\
\left(\mathrm{mmol}^{1-1 / n}\right. \\
\left.\mathrm{kg}^{-1} \mathrm{~L}^{1 / n}\right)\end{array}$ & $1 / n$ & $\mathbf{R}^{2}$ \\
\hline 283 & 270.0 & 26.74 & 0.0012 & 0.999 & 1.002 & 0.0025 & 0.994 \\
\hline 293 & 281.0 & 25.57 & 0.0011 & 0.997 & 1.321 & 0.0991 & 0.984 \\
\hline 303 & 284.11 & 25.24 & 0.0010 & 0.998 & 1.3321 & 0.0031 & 0.988 \\
\hline
\end{tabular}

\section{The Thermodynamic Study}

The effect of temperature on sorption was investigated in the temperature range of 283-313 K. It was observed that the adsorption increased with the increases in temperature (Figure 10a), which reveals that the process may be chemisorption, and the reverse may be true for physisorption. This increase in the rate of adsorption with temperature may be due to the efficient flow of sorbate molecules against the concentration gradient or the transport of sorbate through the energy barrier. This may also create some new sites on the surface of the sorbent $[48,49]$. The thermodynamic parameters, such as Gibbs free energy change $(\Delta G)$, enthalpy $(\Delta H)$, and entropy $(\Delta S)$, were determined by using the relations below $[50,51]$.

$$
\begin{gathered}
\Delta G=-R T \ln k \\
\ln \mathrm{K}=\frac{\Delta S}{R}-\frac{\Delta H}{R T} \\
\Delta G=\Delta H-T \Delta S
\end{gathered}
$$
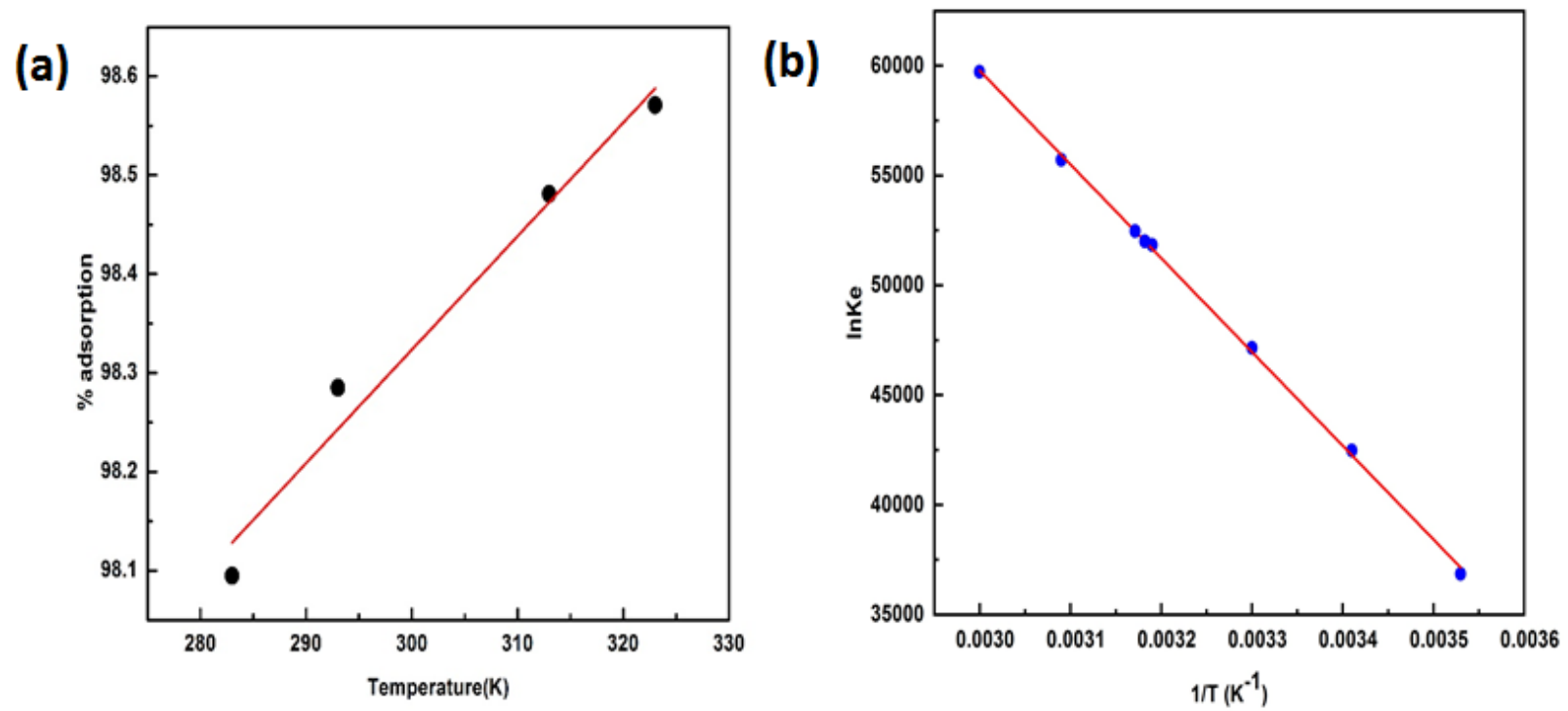

Figure 10. (a) Effect of temperature on adsorption, and (b) determination of thermodynamic parameters by the Van 't Hoff equation.

The calculated value of $\Delta G$ was $-15.75 \mathrm{~kJ} \mathrm{~mol}^{-1}$, revealing that the adsorption of the $\mathrm{Cd}(\mathrm{II})$ ion onto $\mathrm{AC}$ is feasible and spontaneous [52]. The magnitude of $\Delta H$ was $16.24 \mathrm{~kJ} \mathrm{~mol}^{-1}$, showing that the sorption mechanism is endothermic $[53,54]$. The $\Delta S$ as determined from the intercept of the graph of lnke against $1 / T$ was $58.66 \mathrm{~J} \mathrm{~mol}^{-1}$ (Figure 10b), 
reflecting the sorbate/sorbent complex stability [51,55]. The thermodynamic results are summarized in Table 3 and were calculated by using a second-order polynomial relationship.

Table 3. Thermodynamic parameters of adsorption of Cd (II) ion onto AC.

\begin{tabular}{|c|c|c|c|}
\hline Temperature (K) & $\Delta G\left(\mathrm{~kJ} \mathrm{~mol}^{-1}\right)$ & $\Delta H\left(\mathrm{~kJ} \mathrm{~mol}^{-1}\right)$ & $\Delta S\left(\mathrm{~J} \mathrm{~mol}^{-1} \mathrm{~K}^{-1}\right)$ \\
\hline 283 & -15.75 & 16.24 & 58.66 \\
\hline 293 & -16.30 & 16.72 & 58.66 \\
\hline 313 & -16.86 & 17.32 & 58.66 \\
\hline 323 & -17.42 & 17.82 & 58.66 \\
\hline
\end{tabular}

\section{DFT Study}

To gain deeper insights into the interactions of the $\mathrm{Cd}(\mathrm{II})$ ion with the activated carbon, density functional theory (DFT) simulations were performed, which were recently frequently utilized in combination with experimental studies to understand the mechanism of the adsorption process $[42,56,57]$. The DFT simulations were performed by DMol3 code $[58,59]$ using the spin unrestricted density functional theory along with the PerdewBurke-Ernzerhof (PBE) formulation in combination with double numerical basis sets involving polarization functions (DNP). The Hirshfeld charge density method was used for the population analysis. The adsorption energies were calculated using the formula:

$$
E_{\mathrm{ad}}=E_{\text {complex }}-\left(E_{\mathrm{AC}}+E_{\mathrm{Cd}(\mathrm{II})}\right)
$$

where $E_{\text {complex }}$ is the total electronic energy of the complex system (Cd (II) ion adsorbed over activated carbon), $E_{\mathrm{AC}}$ and $E_{\mathrm{Cd}(\mathrm{II})}$ are the energies of activated carbon and Cd (II) ion separately.

The optimized geometries are represented in Figure 11, and values of adsorption energies, intermolecular distances, and charge transfers are collected in Table 4. Four different adsorption modes of $\mathrm{Cd}$ (II) ion onto activated carbon (AC) are simulated, which are named CMP-1, CMP-2, CMP-3, and CMP-4, as illustrated in Figure 11. In CMP-1, the $\mathrm{Cd}$ (II) ion interacted with the $\mathrm{O}$ atom of $\mathrm{C}=\mathrm{O}$ bond present on the surface of $\mathrm{AC}$. The geometry optimization revealed that the $\mathrm{Cd}$ (II) ion formed an intermolecular bond of a bond distance of $2.39 \AA$, while the adsorption energy $\left(E_{\mathrm{ad}}\right)$ showed that the $E_{\mathrm{ad}}$ value for this complex was $-9.20 \mathrm{eV}$, which showed the stronger interaction. The Hirshfeld charge analysis depicts that a larger charge transfer $(0.59$ e) occurred from the $\mathrm{Cd}$ (II) ion to the $\mathrm{O}$ atom of the surface, which resulted in a stronger intermolecular bond. In CMP-2, the Cd (II) ion interacted with the $\mathrm{O}$ atoms of the $\mathrm{NO}_{2}$ group and the $\mathrm{O}$ atom of the $\mathrm{C}=\mathrm{O}$ group at the edge of the AC. The optimization shows that the $\mathrm{Cd}$ (II) ion formed intermolecular bonds with one $\mathrm{O}$ atom of the $\mathrm{NO}_{2}$ group and with the $\mathrm{O}$ atom of the $\mathrm{C}=\mathrm{O}$ group. The bond distances noticed for this interaction were 2.25 and $2.41 \AA$, respectively. The $E_{a d}$ energy and Hirshfeld charge transfer value obtained for this complex was $-10.03 \mathrm{eV}$ and $0.70 \mathrm{e}$. This larger $\mathrm{E}_{\mathrm{ad}}$ value and higher charge transfer value demonstrate that the formation of this complex is highly thermodynamically stable. In CMP-3, the Cd (II) ion interacted with the $\mathrm{SO}_{3} \mathrm{H}$ group at the edge of $\mathrm{AC}$. The intermolecular bond distances calculated for this complex were 2.98 and $2.92 \AA$, respectively. The $E_{\text {ad }}$ and charge transfer values noticed for this complex were $-9.54 \mathrm{eV}$ and $0.59 \mathrm{e}$. In CMP-4, the Cd (II) ion was placed over the top of the hexagonal ring of the AC. The geometry optimization reveals that the $\mathrm{Cd}$ (II) ion formed weak intermolecular bonds in this complex with binding distances up to $3.45 \AA$. Smaller $E_{\mathrm{ad}}$ and charge transfer values obtained for this complex was $-0.45 \mathrm{eV}$ and $0.23 \mathrm{e}$. In summary, the DFT simulations showed that the AC has a higher affinity for the adsorption of $\mathrm{Cd}$ (II) ions due to the presence of higher negative active sites, i.e., $\mathrm{N}, \mathrm{O}$, and $\mathrm{S}$ atoms. The $\mathrm{Cd}$ formed stronger bonds with these active sites, which resulted in stronger adsorption. The larger negative values depict that the adsorption process is spontaneous and thermodynamically stable. In CMP-4, the Cd (II) ion was placed above the aromatic 
ring of the activated carbon. The bond lengths mentioned in Table 4 for CMP-4 are weak intermolecular bonds between the $\mathrm{C}$ atoms of the aromatic ring and the $\mathrm{Cd}$ ion. The top view and the side view of CMP-4 are illustrated in Figure 12, where the bond lengths are shown with a dotted line.

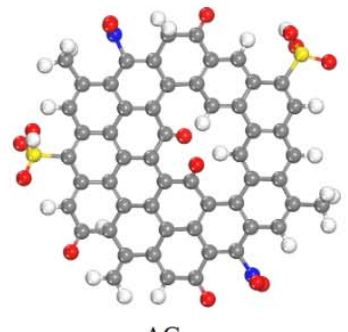

$\mathrm{AC}$

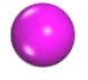

$\mathrm{Cd}(\mathrm{II})$

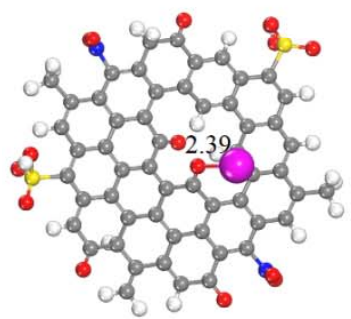

CMP-1

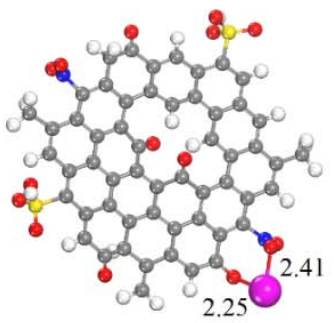

CMP-2

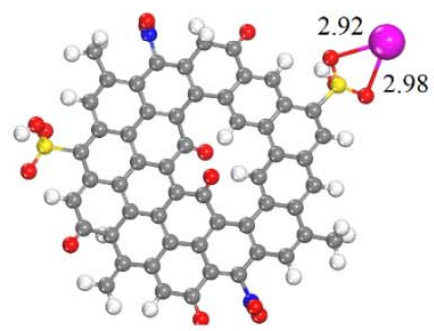

CMP-3

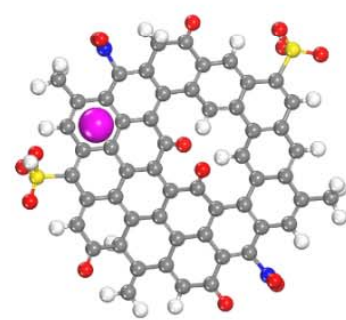

CMP-4

$\bigcirc \mathrm{H} \odot \mathrm{c} \odot \mathrm{N} \odot \mathrm{O}$

Figure 11. Graphical representation of optimized geometry of AC and Cd (II)@AC complexes. Bond distances are in $\AA$.

Table 4. Computed bond distance $(\AA)$, adsorption energy $\left(E_{\mathrm{ad}}, \mathrm{eV}\right)$, and Hirshfeld charge transfer $\left(\Delta Q_{\mathrm{CT}}, \mathrm{e}\right)$.

\begin{tabular}{cccc}
\hline Complex & Bond Distance & $\boldsymbol{E}_{\mathbf{a d}}$ & $\Delta \boldsymbol{Q}_{\mathrm{CT}}$ \\
\hline CMP-1 & 2.39 & -9.21 & 0.59 \\
\hline CMP-2 & $2.25,2.41$ & -10.03 & 0.70 \\
\hline CMP-3 & $2.92,2.98$ & -9.55 & 0.59 \\
\hline CMP-4 & $3.45,3.41,3.39$ & -0.45 & 0.23 \\
\hline
\end{tabular}

In CMP-1, -2 , and -3 , chemical bonds formed between the $\mathrm{O}$ atoms and the $\mathrm{Cd}$ ion, which is justified by charge transfers as shown in Table 4. Larger charge transfers occurred between the $\mathrm{O}$ atoms and the $\mathrm{Cd}$ ion during complexation, and the value above 0.25 e clearly indicates the chemical bond formation. To further verify this statement, we computed the partial density of states analysis for the complex-1, as depicted in Figure 13. The PDOS clearly shows that there is stronger overlapping at the Femi level between the $\mathrm{d}$ orbital of the $\mathrm{Cd}$ ion and the $\mathrm{p}$ orbital of the $\mathrm{O}$ atom, evidenced by the strong interaction and confirming the chemical bond formation between the $\mathrm{Cd}$ ion and the $\mathrm{O}$ atom. 


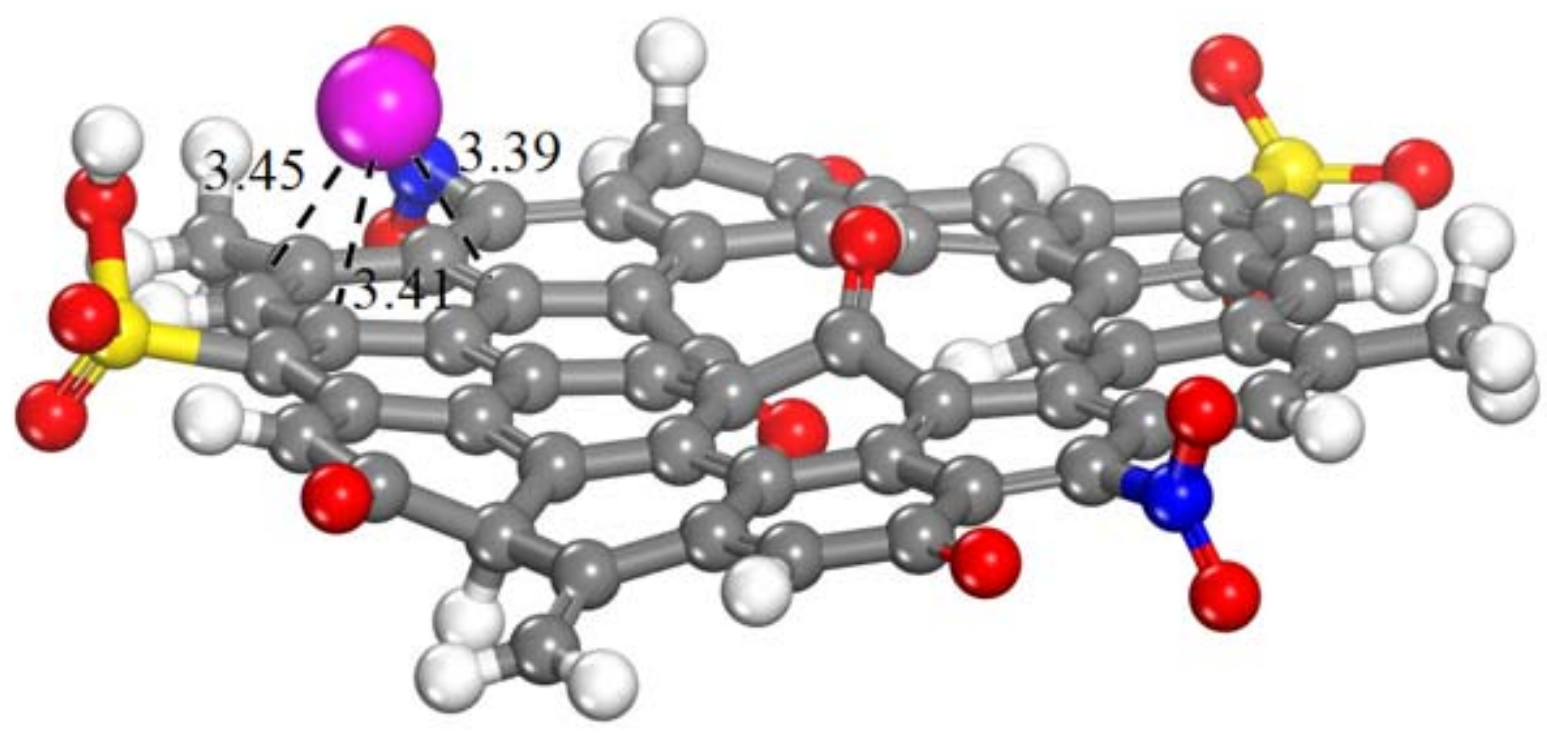

H०c?

Figure 12. Graphical representation of optimized geometry of AC and Cd (II)@AC complexes. Bond distances are in $\AA$ (dotted line).

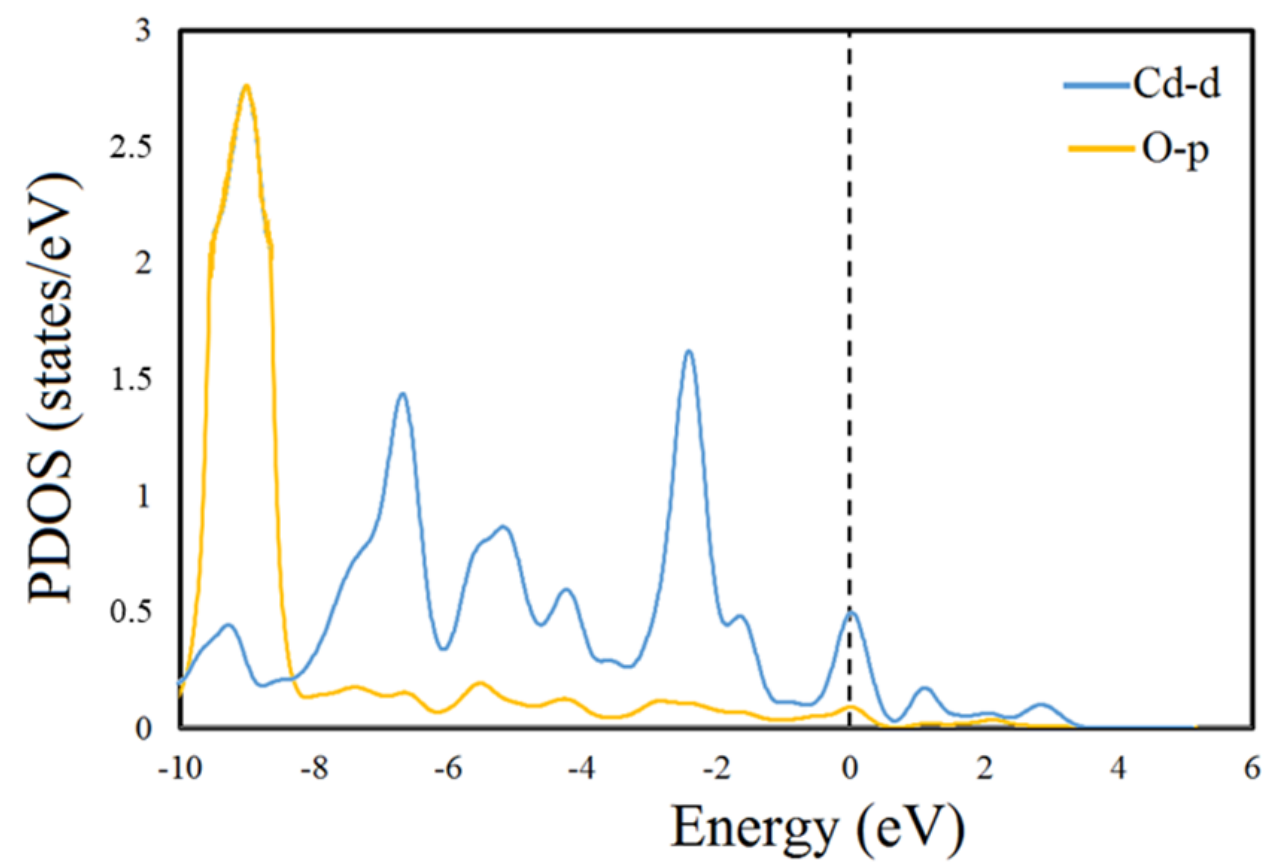

Figure 13. Graphical representation of partial density of state (PDOS) of optimized geometry of AC and Cd (II)@AC complexes.

\section{Conclusions}

The starch-based activated carbon was proven to be an efficient adsorbent for remediation of cadmium ions from the water system. The results show that the metal ion adsorption capacity onto activated carbon increased with increasing $\mathrm{pH}$, and it was found that maximum adsorption ( $284 \mathrm{mg} \mathrm{g}^{-1}$ ) of $\mathrm{Cd}$ (II) was achieved at a $\mathrm{pH}$ solution of about 6. In thermodynamic studies, the negative values of $\Delta G$ at all temperatures exhibited the spontaneous nature of $\mathrm{Cd}^{2+}$ adsorption on $\mathrm{AC}$. The values of $Q_{\max }$. calculated from Langmuir isotherms were also increased with increasing temperature, which also confirmed the endothermic nature of cadmium adsorption. Moreover, the DFT study shows that the 
AC has a stronger affinity for the adsorption of Cd (II) ions due to the presence of highly active sites. The shorter bond distances in CMP-1, CMP-2, and CMP-4 reveal that the Cd (II) strongly interacts with various active sites of the AC. Therefore, the $E_{\text {ad }}$ values are highly negative, which ranges from $-43.41 \mathrm{~kJ} \mathrm{~mol}^{-1}$ to $-967.74 \mathrm{~kJ} \mathrm{~mol}^{-1}$, and indicates that the adsorption process is spontaneous and thermodynamically feasible. The larger charge transfer $(0.23$ e to 0.70 e) provides evidence of the presence of a stronger intermolecular bond between the $\mathrm{Cd}$ (II) ions and AC.

Author Contributions: Conceptualization, S.M.; methodology, S.U.J.; software, A.A.K.; validation, S.U.; formal analysis, K.B.; investigation, B.B.; resources, S.U.J.; data curation, S.U.J.; writing—original draft preparation, S.U.J.; writing—review and editing, S.U.J.; visualization, Z.S.; supervision, S.U.J.; project administration, S.U.J. All authors have read and agreed to the published version of the manuscript.

Funding: This research received no external funding.

Institutional Review Board Statement: Not Applicable.

Informed Consent Statement: Not Applicable.

Data Availability Statement: Not Applicable.

Conflicts of Interest: The authors have no conflict of interest.

\section{References}

1. Ali, Z.; Ahmad, R.; Khan, A. Functionalized nanospheres for efficient sequestration of cadmium ions. RSC Adv. 2014, 4, 50056-50063. [CrossRef]

2. Hasany, S.M.; Ahmad, R. The potential of cost-effective coconut husk for the removal of toxic metal ions for environmen-tal protection. J. Environ. Manage. 2006, 81, 286-295. [CrossRef] [PubMed]

3. Fiberg, L.; Nordberg, G.; Vouk, V. Handbook of the Toxicology of Metals; Elsevier: New York, NY, USA, 1986 ; Volume 2.

4. Peña-Guzmán, C.; Ulloa-Sánchez, S.; Mora, K.; Helena-Bustos, R.; López, E.; Alvarez, J.; Rodriguez-Pinzón, M. Emerging pollutants in the urban water cycle in Latin America: A review of the current literature. J. Environ. Manag. 2019, 237, 408-423. [CrossRef] [PubMed]

5. Teodosiu, C.; Gilca, A.-F.; Barjoveanu, G.; Fiore, S. Emerging pollutants removal through advanced drinking water treat-ment: A review on processes and environmental performances assessment. J. Clean. Prod. 2018, 197, 1210-1221. [CrossRef]

6. Wen, X.; Wu, P.; Xu, K.; Wang, J.; Hou, X. On-line precipitation-dissolution in knotted reactor for thermospray flame fur-nace AAS for determination of ultratrace cadmium. Microchem. J. 2009, 91, 193-196. [CrossRef]

7. Arnold, R.; Augier, C.; Baker, J.; Barabash, A.; Basharina-Freshville, A.; Blondel, S.; Blot, S.; Bongrand, M.; Boursette, D.; Brudanin, V. Measurement of the $2 \vee \beta \beta$ decay half-life and search for the $0 \vee \beta \beta$ decay of Cd 116 with the NEMO-3 detector. Phys. Rev. D. 2017, 95, 012007. [CrossRef]

8. Godt, J.; Scheidig, F.; Grosse-Siestrup, C.; Esche, V.; Brandenburg, P.; Reich, A.; Groneberg, D.A. The toxicity of cadmium and resulting hazards for human health. J. Occup. Med. Toxicol. 2006, 1, 1-6. [CrossRef]

9. Davis, A.C.; Wu, P.; Zhang, X.; Hou, X.; Jones, B.T. Determination of Cadmium in Biological Samples. Appl. Spectrosc. Rev. 2006, 41, 35-75. [CrossRef]

10. Wen, X.; Yang, Q.; Yan, Z.; Deng, Q. Determination of cadmium and copper in water and food samples by dispersive liquid-liquid microextraction combined with UV-vis spectrophotometry. Microchem. J. 2011, 97, 249-254. [CrossRef]

11. Ma, W.; Song, X.; Pan, Y.; Cheng, Z.; Xin, G.; Wang, B.; Wang, X. Adsorption behavior of crystal violet onto opal and reuse feasibility of opal-dye sludge for binding heavy metals from aqueous solutions. Chem. Eng. J. 2012, 193-194, 381-390. [CrossRef]

12. Waalkes, M.P.; Rehm, S.; Riggs, C.W.; Bare, R.M.; DeVor, D.E.; Poirier, L.A.; Wenk, M.L.; Henneman, J.R.; Balaschak, M.S. Cadmium carcinogenesis in male Wistar [Crl:(WI)BR] rats: Dose-response analysis of tumor induction in the prostate and testes and at the injection site. Cancer Res. 1988, 48, 4656-4663. [PubMed]

13. Seidal, K.; Jorgensen, N.; Elinder, C.; Sjögren, B.; Vahter, M. Fatal cadmium-induced pneumonitis. Scand. J. Work. Environ. Health 1993, 19, 429-431. [CrossRef] [PubMed]

14. Li, H.; Gao, P.; Cui, J.; Zhang, F.; Wang, F.; Cheng, J. Preparation and Cr (VI) removal performance of corncob activated carbon. Environ. Sci. Pollut. Res. 2018, 25, 20743-20755. [CrossRef] [PubMed]

15. Fuertes, A.B.; Valle-Vigón, P.; Sevilla, M. One-step synthesis of silica@ resorcinol-formaldehyde spheres and their applica-tion for the fabrication of polymer and carbon capsules. Chem. Commun. 2012, 48, 6124-6126. [CrossRef]

16. Lo, K.-H.; Lu, C.-W.; Lin, W.-H.; Chien, C.-C.; Chen, S.-C.; Kao, C.-M. Enhanced reductive dechlorination of trichloroe-thene with immobilized Clostridium butyricum in silica gel. Chemosphere 2020, 238, 124596. [CrossRef]

17. Chung, K.-T. The significance of azo-reduction in the mutagenesis and carcinogenesis of azo dyes. Mutat. Res. Rev. Genet. Toxicology. 1983, 114, 269-281. [CrossRef] 
18. Uddin, M.K. A review on the adsorption of heavy metals by clay minerals, with special focus on the past decade. Chem. Eng. J. 2017, 308, 438-462. [CrossRef]

19. Ayangbenro, A.S.; Babalola, O.O. A New Strategy for Heavy Metal Polluted Environments: A Review of Microbial Biosorbents. Int. J. Environ. Res. Public Health 2017, 14, 94. [CrossRef]

20. Khan, A.A.; Esrafili, M.D.; Ahmad, A.; Hull, E.; Ahmad, R.; Jan, S.U.; Ahmad, I. A computational study on the characteris-tics of open-shell $\mathrm{H}$-bonding interaction between carbamic acid $\left(\mathrm{NH}_{2} \mathrm{COOH}\right)$ and $\mathrm{HO}_{2}, \mathrm{HOS}$ or $\mathrm{HSO}$ radicals. J. Mol. Model. 2019, 25, 189. [CrossRef]

21. Allen, N.; Dai, C.; Hu, Y.; Kubicki, J.D.; Kabengi, N. Adsorption Study of $\mathrm{Al}^{3+}, \mathrm{Cr}^{3+}$, and $\mathrm{Mn}^{2+}$ onto Quartz and Corun-dum using Flow Microcalorimetry, Quartz Crystal Microbalance, and Density Functional Theory. ACS Earth Space Chem. 2019, 3 , 432-441. [CrossRef]

22. Acelas, N.Y.; Flórez, E. Density functional theory studies of the adsorption of Cr (VI) on Fe-(hydr) oxide: Gibbs free energies and pH effect. J. Physics: Conf. Ser. 2019, 1247, 012051. [CrossRef]

23. Yang, R.T. Adsorbents: Fundamentals and Applications; Wiley-VCH Verlag GmbH: Weinheim, Germany, 2003.

24. Tayone, J. Spectrophotometric determination of chromium (VI) in canned fruit juices. Int. J. Sci. Basic Appl. Researchm. 2015, 19, 426-432.

25. Shirazani, M.T.; Bakhshi, H.; Rashidi, A.; Taghizadeh, M. Starch-based activated carbon micro-spheres for adsorption of methane with superior performance in ANG technology. J. Environ. Chem. Eng. 2020, 8, 103910. [CrossRef]

26. Yang, K.; Pan, T.; Zhao, Q.; Chen, C.; Zhu, X.; Wang, P.; Chen, B. Dual-function ultrafiltration membrane constructed from pure activated carbon particles via facile nanostructure reconstruction for high-efficient water purification. Carbon 2020, 168, 254-263. [CrossRef]

27. Tyagi, A.; Banerjee, S.; Singh, S.; Kar, K.K. Biowaste derived activated carbon electrocatalyst for oxygen reduction reac-tion: Effect of chemical activation. Int. J. Hydrog. Energy 2020, 45, 16930-16943. [CrossRef]

28. Singh, G.; Dwivedi, S. Decolorization and degradation of Direct Blue-1 (Azo dye) by newly isolated fungus Aspergillus terreus GS28, from sludge of carpet industry. Environ. Technol. Innov. 2020, 18, 100751. [CrossRef]

29. Karim, S.A.; Al-Gubury, H.Y.; Alrazzak, N.A. The Synthesis of a Novel Azo Dyes and Study of Photocatalytic Degradation. J. Phys. Conf. Ser. 2019, 1294, 052054. [CrossRef]

30. Banerjee, M.; Basu, R.K.; Das, S.K. Cu (II) removal using green adsorbents: Kinetic modeling and plant scale-up design. Environ. Sci. Pollut. Res. 2019, 26, 11542-11557. [CrossRef]

31. Maleki, B.; Reiser, O.; Esmaeilnezhad, E.; Choi, H.J. $\mathrm{SO}_{3} \mathrm{H}$-dendrimer functionalized magnetic nanoparticles $\left(\mathrm{Fe}_{3} \mathrm{O}_{4} @ \mathrm{DNH}\right.$ $\left.\left(\mathrm{CH}_{2}\right)_{4} \mathrm{SO}_{3} \mathrm{H}\right)$ : Synthesis, characterization and its application as a novel and heterogeneous catalyst for the one-pot syn-thesis of polyfunctionalized pyrans and polyhydroquinolines. Polyhedron 2019, 162, 129-141. [CrossRef]

32. Rafatullah, M.; Ismail, S.; Ahmad, A. Optimization Study for the Desorption of Methylene Blue Dye from Clay Based Adsorbent Coating. Water 2019, 11, 1304.

33. Naushad, M.; Alqadami, A.A.; AlOthman, Z.A.; Alsohaimi, I.H.; Algamdi, M.S.; Aldawsari, A.M. Adsorption kinetics, isotherm and reusability studies for the removal of cationic dye from aqueous medium using arginine modified activated car-bon. J. Mol. Liquids. 2019, 293, 111442. [CrossRef]

34. Cheng, S.; Zhang, L.; Ma, A.; Xia, H.; Peng, J.; Li, C.; Shu, J. Comparison of activated carbon and iron/cerium modified activated carbon to remove methylene blue from wastewater. J. Environ. Sci. 2018, 65, 92-102. [CrossRef] [PubMed]

35. Khandaker, S.; Toyohara, Y.; Saha, G.C.; Awual, R.; Kuba, T. Development of synthetic zeolites from bio-slag for cesium adsorption: Kinetic, isotherm and thermodynamic studies. J. Water Process Eng. 2020, 33, 101055. [CrossRef]

36. Sharma, G.; Naushad, M. Adsorptive removal of noxious cadmium ions from aqueous medium using activated car-bon/zirconium oxide composite: Isotherm and kinetic modelling. J. Mol. Liq. 2020, 310, 113025. [CrossRef]

37. Yuh-Shan, H. Citation review of Lagergren kinetic rate equation on adsorption reactions. Scientometrics 2004, 59, 171-177. [CrossRef]

38. Ho, Y.-S.; McKay, G. The kinetics of sorption of divalent metal ions onto sphagnum moss peat. Water Res. 2000, 34, 735-742. [CrossRef]

39. Brito, S.M.d.; Cordeiro, J.L.C.; Ramalho, L.d.; Oliveira, J.F.R. Eriochrome black adsorption on yellow passion fruit peel (Passiflora edulis f. Flavicarpa) treated with sodium hydroxide and nitric acid: Study of adsorption isotherms, kinetic models and thermodynamic parameters. SN Appl. Sci. 2019, 1, 1226. [CrossRef]

40. Kazeem, T.S.; Zubair, M.; Daud, M.; Mu'azu, N.D.; Al-Harthi, M.A. Graphene/ternary layered double hydroxide compo-sites: Efficient removal of anionic dye from aqueous phase. Korean J. Chem. Eng. 2019, 36, 1057-1068. [CrossRef]

41. Kim, D.-W.; Wee, J.-H.; Yang, C.-M.; Yang, K.S. Efficient removals of Hg and Cd in aqueous solution through NaOH-modified activated carbon fiber. Chem. Eng. J. 2020, 392, 123768. [CrossRef]

42. Jan, S.U.; Ahmad, A.; Khan, A.A.; Melhi, S.; Ahmad, I.; Sun, G.; Chen, C.-M.; Ahmad, R. Removal of azo dye from aqueous solution by a low-cost activated carbon prepared from coal: Adsorption kinetics, isotherms study, and DFT simulation. Environ. Sci. Pollut. Res. 2021, 28, 10234-10247. [CrossRef]

43. Desta, M.B. Batch sorption experiments: Langmuir and Freundlich isotherm studies for the adsorption of textile metal ions onto teff straw (Eragrostis tef) agricultural waste. J. Thermodyn. 2013, 2013, 375830. [CrossRef]

44. Liu, Y.; Liu, Y.-J. Biosorption isotherms, kinetics and thermodynamics. Sep. Purif. Technol. 2008, 61, 229-242. [CrossRef] 
45. Zhang, J.; Shao, J.; Jin, Q.; Li, Z.; Zhang, X.; Chen, Y.; Zhang, S.; Chen, H. Sludge-based biochar activation to enhance Pb(II) adsorption. Fuel 2019, 252, 101-108. [CrossRef]

46. Fajarwati, F.I.; Anugrahwati, M.; Yanti, I.; Safitri, R.A.; Yeni; Yuanita, E. Adsorption Study of Methylene Blue and Eriochrome Black T Dyes on Activated Carbon and Magnetic Carbon Composite. IOP Conf. Ser. Mater. Sci. Eng. 2019, 599, 012025. [CrossRef]

47. Alkherraz, A.M.; Ali, A.K.; Elsherif, K.M. Removal of Pb (II), Zn (II), Cu (II) and Cd (II) from aqueous solutions by ad-sorption onto olive branches activated carbon: Equilibrium and thermodynamic studies. Chem. Int. 2020, 6, 11-20.

48. Ahmad, R.; Saeed, M.M.; Ali, A.; Zaidi, J.H. Removal of Tm(III) ions from aqueous solution using PAN-incorporated sol-gel matrices. Radiochim. Acta 2007, 95, 451-457. [CrossRef]

49. Liu, Y.; Xu, H. Equilibrium, thermodynamics and mechanisms of $\mathrm{Ni}^{2+}$ biosorption by aerobic granules. Biochem. Eng. J. 2007, 35, 174-182. [CrossRef]

50. Ali, Z.; Ahmad, R.; Khan, A.; Adalat, B. Organic-inorganic hybrids: An efficient extractant of environmental mercury ions. Mater. Res. Express 2018, 5, 075007. [CrossRef]

51. Lima, E.C.; Hosseini-Bandegharaei, A.; Moreno-Piraján, J.C.; Anastopoulos, I. A critical review of the estimation of the thermodynamic parameters on adsorption equilibria. Wrong use of equilibrium constant in the Van't Hoof equation for calcu-lation of thermodynamic parameters of adsorption. J. Mol. Liq. 2019, 273, 425-434. [CrossRef]

52. Chang, Y.; Lai, J.-Y.; Lee, D.-J. Thermodynamic parameters for adsorption equilibrium of heavy metals and dyes from wastewaters: Research updated. Bioresour. Technol. 2016, 222, 513-516. [CrossRef]

53. Kim, H.; Cho, H.J.; Narayanan, S.; Yang, S.; Furukawa, H.; Schiffres, S.; Li, X.; Zhang, Y.-B.; Jiang, J.; Yaghi, O.M. Character-ization of adsorption enthalpy of novel water-stable zeolites and metal-organic frameworks. Sci. Rep. 2016, 6, 19097. [CrossRef] [PubMed]

54. Liu, Y. Is the Free Energy Change of Adsorption Correctly Calculated? J. Chem. Eng. Data 2009, 54, 1981-1985. [CrossRef]

55. Peydayesh, M.; Bolisetty, S.; Mohammadi, T.; Mezzenga, R. Assessing the Binding Performance of Amyloid-Carbon Mem-branes toward Heavy Metal Ions. Langmuir 2019, 35, 4161-4170. [CrossRef] [PubMed]

56. Ghazi, Z.A.; Khattak, A.M.; Iqbal, R.; Ahmad, R.; Khan, A.A.; Usman, M.; Nawaz, F.; Ali, W.; Felegari, Z.; Jan, S.U. Adsorptive removal of $\mathrm{Cd}^{2+}$ from aqueous solutions by a highly stable covalent triazine-based framework. N. J. Chem. 2018, 42, 10234-10242. [CrossRef]

57. Hussain, M.; Khaliq, M.N.; Nisar, A.; Khan, P.D.M.; Karim, S.; Khan, A.A.; Yi, P.D.X.; Maqbool, M.; Ali, G. TiO 2 nanotube array-modified electrodes for L-cysteine biosensing: Experimental and density-functional theory study. Nanotechnology 2020, 31, 505501. [CrossRef]

58. Delley, B. An all-electron numerical method for solving the local density functional for polyatomic molecules. J. Chem. Phys. 1990, 92, 508-517. [CrossRef]

59. Delley, B. From molecules to solids with the DMol 3 approach. J. Chem. Phys. 2000, 113, 7756-7764. [CrossRef] 